\title{
URBAN TRAFFIC MODELING WITH MICROSCOPIC APPROACH USING CELLULAR AUTOMATA
}

\author{
İsmail Kurnaz
}

Original scientific paper Traffic jam is one of the hardest problems of the crowded cities, and it needs to be solved. In this study, the effect of the minimum speed limit signs in addition to the maximum speed signs and their locations in traffic flow has been examined by using cellular automata (CA). Urban traffic is modeled by two dimensional CA. The model includes traffic signs, traffic lights and some kinds of vehicles (such as automobiles, vans, buses, metro buses) that are often encountered in traffic.

Keywords: application virtualization; cellular automata; computer graphics; computer simulation; transportation systems

\section{Modeliranje gradskog prometa mikroskopskim pristupom primjenom celularnih automata}

Izvorni znanstveni članak Zastoj prometa je jedan od najvećih problema prenapućenih gradova i potrebno ga je riješiti. U ovom se radu, primjenom celularnih automata (CA), uz znakove maksimalne brzine ispitivao učinak znakova minimalnog ograničenja brzine i njihova lokacija u prometu. Gradski je promet modeliran dvodimenzionalnim CA. Model uključuje prometne znakove, prometna svjetla i neke vrste vozila (automobili, furgoni, autobusi, metro autobusi) koja su česta u prometu.

Ključne riječi: virtualizacija aplikacije; celularni automati; računalna grafika; simulacija na računalu; prijevozni sustavi

\section{Introduction}

One of the important problems in heavy traffic is the management of traffic flow. For analyzing traffic states simulation systems have been frequently chosen because of economical reasons. In traffic simulation systems models can be constructed using several techniques such as CA, Hierarchical Synchronized State Machines, etc. [1]. While modeling traffic behaviors CA are often preferred rather than the others, since it is easier to construct, analyze and understand them. While highway traffic can be simulated by $1 \mathrm{D}$ CA, urban traffic needs to be simulated by 2D CA. [2]

Wolfram's work using Rule 184 can be considered the first study on traffic simulation using CA. In that work Rule 184 was used to simulate vehicle dynamics in the basic one dimensional CA model. [3]

The CA model [4] developed by Nagel and Schreckenberg is one-dimensional. In this model each cell can include only one vehicle in opened and limited circumstances and the cell value is either the speed of the vehicle between 0 to Vmax or gap. At every time step of the simulation, the system modifies itself with the following rules.

- Acceleration: if $\left(\left(d_{\text {ahead }}>v_{\text {vehicle }}+1\right)\right.$ AND $\left(v_{\text {vehicle }}<\right.$ $\left.\left.v_{\max }\right)\right)$ then $v_{\text {vehicle }}=v_{\text {vehicle }}+1$

- Deceleration: if ((current $t_{\text {vehicle }}$ in cell $\left._{i}\right)$ AND $\left(\right.$ ahead $_{\text {vehicle }}$ in $\left.c e l l_{i+j}\right)$ AND $\left.\left(j \leq v_{\text {vehicle }}\right)\right)$ then $v_{\text {vehicle }}=j-$ 1

- Probability: With $p$, if $\left(v_{\text {vehicle }}>0\right)$ then $v_{\text {vehicle }}=$ $v_{\text {vehicle }}-1$

- Movement: Every vehicle moves on $v_{\text {vehicle }}$ site

After Nagel, Schreckenberg and the others [5] implemented two-lane traffic simulation system which has lane changing ability using two-dimensional CA model. The parameters such as symmetry, stochasticity and direction of casualty have increased the model reality.
However this work has not represented the case where the flow in the left lane is faster than in the right lane. [5].

Barlovic and et al [6] have modified the third step of [4]. Randomization probability has determined with Velocity Dependent Randomization Rules (VDRL). VDRL is a function depending on the vehicle speed. Contrary to [4], the randomization probability applies before acceleration step and is not constant.

Highway traffic controlled by traffic lights can be simulated in the one-dimensional CA model developed by Jiang and Wua [2]. Randomization probability in the model is determined by a function which depends on the stopped time of the vehicle at the traffic lights.

Heterogeneous traffic in work zone can be simulated using an improved cellular automata (ICA) model developed by Meng and Weng. There are two kinds of vehicle (light vehicles i.e. cars and heavy vehicles i.e. trucks) in the model. Randomization parameter in the model is calculated as a function. The function parameters are the activity length, the transition length and the volumes of different types of vehicles in the work zone [7]. The work zone is defined by Land Transport Authority (LTA) of Singapore such as advance warning area, transition area, activity area and termination area.

Bham and Benekohal have developed a high fidelity cell based traffic simulation model (CELLSIM) which is employed to implement different traffic scenarios close to reality. This model is built on formulating car-following (CF) logic, acceleration model, deceleration model, the collision avoidance sequence and the driver's reaction time. It is claimed that the model is more detailed than CA models and simpler than CF models [8].

The reality on traffic simulation systems is related to human-induced flow of traffic delays such as attention deficiency, latency of the vehicle in moving, and so on to integrate to the system. These delays often occur when the vehicle begins to move. SlowToStart and Disorder rules have been applied to model both separately and together 
for simulating the delays. When these two rules have been applied to the system together, traffic congestion has decreased [9].

From past to present many studies such as modeling a highway including junction $[9,10]$, traffic flow model for online simulation of traffic [11], modeling traffic flux controlled by traffic lights [2, 12, 13, 14], modeling public transport system based on cruise control [15], analyzing conventional passenger vehicles and cars on mixed traffic flux [16], modeling flow of bicycles and cars in traffic [17] have been implemented using CA.

One of the important parameters for characterizing traffic flow is vehicular time headway. Mauro and Branco have presented two dichotomic model (ENTLN and ENTPIII) and they claim that these models can be useful when vehicular flows are a casual succession of freemoving and constrained vehicles [18]. The ENTPIII model is used [19] for determining time headways laws. In [19], an algorithm is developed for simulating a steady state traffic flow.

In this study focus is placed on the effect of traffic signs limiting the speed at the lower level as well as high level. Traffic signs are placed at different locations at different times. The main problem in simulating traffic using $\mathrm{CA}$ is the implementation of driver reactions. The randomization probability used for optimizing the simulation problem has been determined by using statistical information obtained through observations from [20].

\section{The components of the system}

One of the most intense traffic areas in Ankara (capital city of Türkey) has been chosen as work zone of study. It is a junction of Atatürk Boulevard (1480 m) GMK Boulevard (815 m) - ZiyaGökalp Street (415 m). It is shown in Fig. 1. Traffic in the work zone flows through three lanes. The cell map of the work zone has been formed using $(2 * 3 * 197) \times(2 * 3 * 164)$ cells. Because the length represented by a cell for a vehicle is $7,5 \mathrm{~m}$ in traffic simulation systems modeled by CA. [21]

One of the objectives of the study is to simulate a traffic zone including different types of vehicles. The set of vehicles includes cars, vans, busses and metro busses. A vehicle is placed in 1, 2, 3 or 4 cells according to its length and secure driving distance. Update time of the simulation is 1 second by virtue of [4]. Speeds of vehicles in the system must have integer values because of CA. For instance if a speed of a vehicle is 3 , the real value of speed is $81 \mathrm{~km} / \mathrm{h}(3 \times 7,5 \times 60 \times 60 / 1000)$.

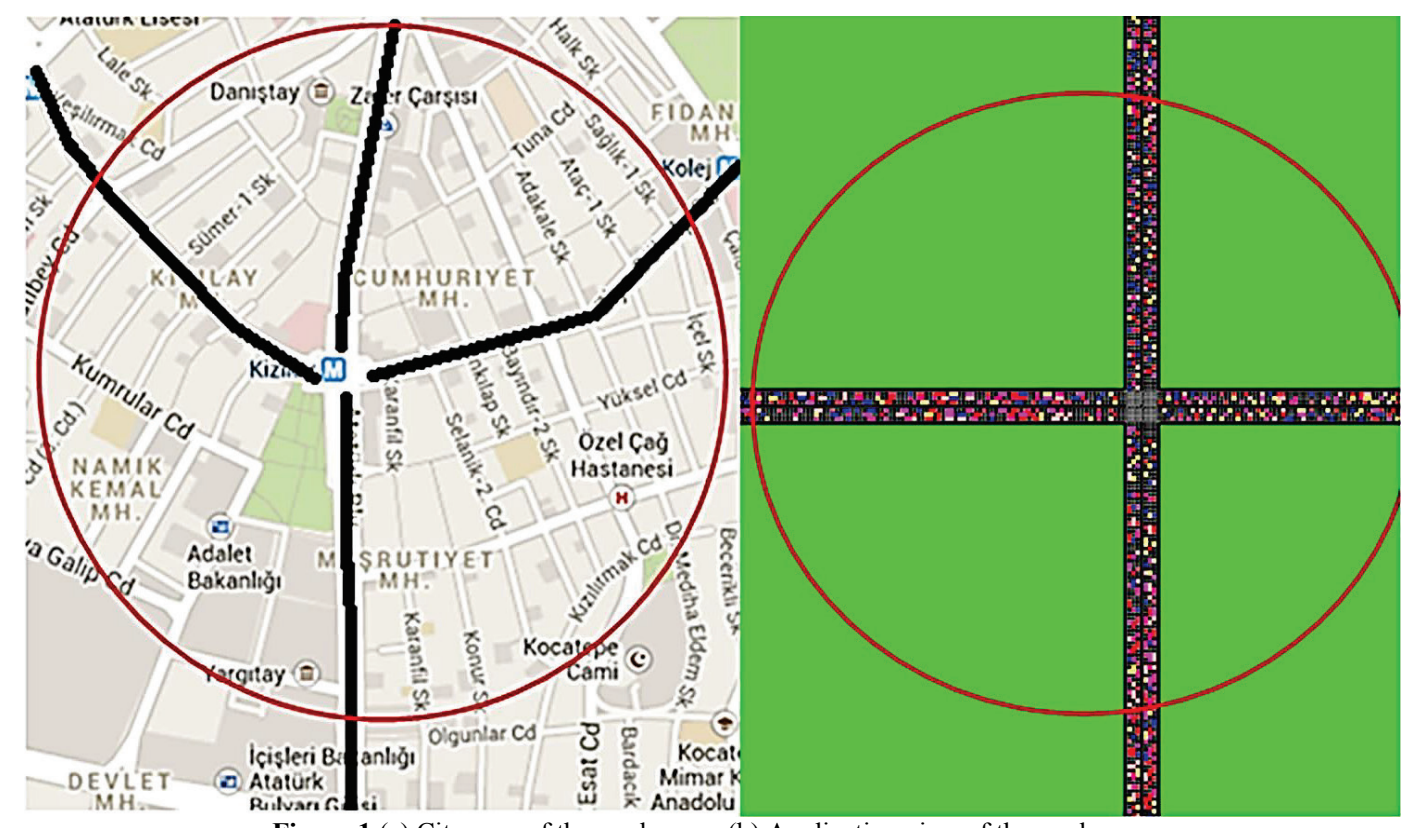

Figure 1 (a) City map of the work zone, (b) Application view of the work zone

The number of vehicles used in this application has been determined by interpreted data from [22] and statistical information obtained from Greater Municipality of Ankara for the last 3 years ( $82 \%$ cars, $12 \%$ vans, $3 \%$ buses and $3 \%$ metrobuses). All the vehicles are simulated in a closed loop.

The intersection in the work zone is managed by traffic lights. Traffic lights are controlled by a finite state machine [23].

Open GL [24] has been employed in the development of the simulation environment. The source codes of the application are written in $\mathrm{C}++$. The new locations of vehicles are graphically updated according to their length and speed in each simulation step.

\section{The structure of the implemented system}

There are several approaches adopted in traffic simulation systems such as macroscopic [25, 26], microscopic [23, 27], mesoscopic and nanoscopic [28]. The differences between these approaches depend on the level of details. For example in macroscopic simulation, traffic flow is formed by some major specifications such as density, velocity and so on. In microscopic simulation some additional specifications such as weather conditions, vehicle properties, and so on, are taken into account in running the simulation. In this study our traffic simulation process has been implemented using the microscopic approach. 
The application developed in this work consists of three parts: setting up the initial values, drawing the graphical picture and processing the CA model.

\subsection{Setting up the initial values}

Before the simulation starts, the vehicles whose locations depend on $[20,22]$ are placed in the cells. There are different speed limits in traffic for different types of vehicles. For instance while speed limit is $70 \mathrm{~km} / \mathrm{h}$ for a car, it is $64 \mathrm{~km} / \mathrm{h}$ for a van. So the speed limit for a vehicle changes according to the vehicle type. Different speed limits (minimum and maximum) are assigned to vehicles as parametric values in the system to accomplish the objective of the study.

\subsection{Drawing graphics}

There are two cell maps in the system: logical map and graphical map. Both maps in the system represent vehicles based on their velocities and lengths. In logic map if a cell value is 'true', it is understood that it has a vehicle or a part of vehicle (since a vehicle length can be $1,2,3$ or 4 cells in length). If a cell value is 'false', there is no vehicle in that location. Source code is written separately for updating logical map, because traffic flow is two-way in the system. Logical map is represented graphically either with vehicle colors (such as red, blue, and etc.) or gap color (black) in graphical map shown in Fig. 1b. The cell value which is either true or false determines a vehicle's behavior (acceleration, deceleration, and stop) in the CA model. Vehicle states are saved to database for each simulation step. Fig. 2 shows the vehicle velocity values in each lane while simulation is going on.

\begin{tabular}{|c|c|c|c|c|c|c|c|c|c|c|c|c|c|c|c|c|c|c|c|c|c|c|c|}
\hline \multirow{2}{*}{ Time } & \multirow{2}{*}{ Lane } & \multicolumn{22}{|c|}{ Cell Map of Atatürk Boulevard } \\
\hline & & 1 & 2 & 3 & 4 & 5 & 8 & 7 & 8 & 9 & \begin{tabular}{|c|}
10 \\
\end{tabular} & $\ldots$ & 94 & \begin{tabular}{|l|}
95 \\
\end{tabular} & \begin{tabular}{|l|}
58 \\
\end{tabular} & $\ldots$ & \begin{tabular}{|l|}
191 \\
\end{tabular} & \begin{tabular}{|l|}
192 \\
\end{tabular} & \begin{tabular}{|l|}
193 \\
\end{tabular} & \begin{tabular}{|l|}
194 \\
\end{tabular} & \begin{tabular}{|l|}
195 \\
\end{tabular} & \begin{tabular}{|l|}
198 \\
\end{tabular} & 197 \\
\hline \multirow{3}{*}{1} & 0 & 3 & 1 & & 2 & & & 2 & & & & $\ldots$ & & & & $\ldots$ & & & 4 & & & & \\
\hline & 9 & 4 & & & 3 & & & & 4 & 3 & & $\ldots$ & & 9 & & $\ldots$ & 4 & 4 & & & & 3 & \\
\hline & 2 & 4 & & & 3 & & & & & 3 & & $\ldots$ & & 1 & & $\ldots$ & 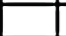 & & 3 & & & & \\
\hline \multirow{3}{*}{2} & 0 & 4 & 1 & & 2 & & 2 & & & & 3 & $\ldots$ & & & & $\ldots$ & 4 & & 4 & & & & \\
\hline & 9 & 3 & & & 3 & 4 & & & 4 & & & $\ldots$ & & & 1 & $\ldots$ & & & 4 & 3 & 3 & & \\
\hline & 2 & & & 2 & 3 & 4 & & 3 & & & & $\ldots$ & & & 1 & $\ldots$ & & & & & & & 4 \\
\hline \multirow{3}{*}{3} & 0 & 4 & & 2 & 2 & & & 3 & & 3 & & $\ldots$ & & 2 & & $\ldots$ & & & & & 4 & & \\
\hline & 1 & 4 & & & 3 & & & & 4 & 4 & & $\ldots$ & & 2 & & $\ldots$ & 4 & & & & & & \\
\hline & 2 & 4 & & & & & 3 & & 4 & 4 & & $\ldots$ & 2 & & & $\ldots$ & & & & 4 & & & \\
\hline \multirow{3}{*}{4} & 0 & 4 & 1 & & & $\overline{2}$ & & 3 & & & & $\ldots$ & 2 & & & $\ldots$ & & & & 4 & & & \\
\hline & 1 & & 1 & 2 & 3 & & & & 4 & & & $\ldots$ & & & & $\ldots$ & 4 & 4 & & & 4 & & \\
\hline & 2 & 4 & & & & 4 & & & & & 4 & $\ldots$ & & & 2 & $\ldots$ & & 4 & & 4 & & & \\
\hline \multirow{3}{*}{5} & 0 & 4 & 1 & & $\overline{2}$ & & & & 3 & & & $\ldots$ & & & 2 & $\ldots$ & & 7 & 4 & & & & \\
\hline & 1 & 4 & & 1 & & & 3 & & 4 & & & $\cdots$ & & & 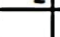 & $\cdots$ & & 4 & 4 & & 4 & 4 & \\
\hline & 2 & 4 & & & & 4 & & & & 4 & & $\ldots$ & & & & $\ldots$ & 4 & & & 4 & 3 & & \\
\hline$\vdots$ & $\vdots$ & $\vdots$ & $\vdots$ & $\vdots$ & $\vdots$ & $\vdots$ & $\vdots$ & $\vdots$ & $\vdots$ & $\vdots$ & $\vdots$ & $\vdots$ & $\vdots$ & $\vdots$ & $\vdots$ & $\vdots$ & $\vdots$ & $\vdots$ & $\vdots$ & $\vdots$ & $\vdots$ & $\vdots$ & $\vdots$ \\
\hline \multirow{3}{*}{114} & 0 & 0 & 1 & 1 & 2 & 2 & 2 & & & & & $\ldots$ & & 0 & & $\ldots$ & 0 & 0 & 0 & & 0 & 0 & \\
\hline & 1 & 0 & 0 & & & 1 & 1 & 1 & & & 2 & $\ldots$ & 0 & 0 & 0 & $\ldots$ & 0 & 0 & 0 & 0 & 0 & & 0 \\
\hline & 2 & 0 & 1 & & 1 & 1 & 1 & & & 2 & 2 & $\ldots$ & 0 & 0 & & $\ldots$ & 7 & 0 & 0 & 0 & 0 & & 0 \\
\hline \multirow{3}{*}{115} & $\overline{0}$ & 0 & 0 & 0 & & 1 & 1 & 1 & & & & $\ldots$ & & & 1 & $\ldots$ & 0 & 0 & 0 & & 0 & 0 & \\
\hline & 9 & 0 & 0 & & & & & 2 & 2 & 2 & 0 & $\ldots$ & 0 & 0 & & $\ldots$ & 0 & 0 & 0 & 0 & 0 & & 0 \\
\hline & 2 & 0 & 1 & & 2 & & 2 & 2 & 2 & & & $\ldots$ & 0 & 0 & & $\ldots$ & & 0 & of & 0 & 0 & & 0 \\
\hline$\vdots$ & $\vdots$ & $\vdots$ & $\vdots$ & $\vdots$ & $\vdots$ & $\vdots$ & $\vdots$ & $\vdots$ & $\vdots$ & $\vdots$ & $\vdots$ & $\vdots$ & $\vdots$ & $\vdots$ & $\vdots$ & $\vdots$ & $\vdots$ & $\vdots$ & $\vdots$ & $\vdots$ & $\vdots$ & $\vdots$ & $\vdots$ \\
\hline \multirow{3}{*}{$N-1$} & 0 & & & & & & 0 & 0 & 0 & & & $\ldots$ & 0 & 0 & & $\ldots$ & 4 & & & & & & \\
\hline & 9 & 4 & & & & 0 & 0 & & & & 2 & $\ldots$ & 0 & & 0 & $\ldots$ & & 4 & 4 & & & & \\
\hline & 2 & & & & 3 & 4 & & 0 & 0 & & 0 & $\ldots$ & 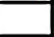 & & & $\ldots$ & & & 3 & \begin{tabular}{l|l}
3 \\
\end{tabular} & & & \\
\hline \multirow{3}{*}{$N$} & 0 & & & & & & & 1 & 1 & 1 & & $\ldots$ & 0 & 0 & & $\ldots$ & & & & & 4 & & \\
\hline & 1 & 0 & 1 & & & 0 & & 1 & & & & $\ldots$ & 0 & & 0 & $\ldots$ & & & 4 & & & 4 & \\
\hline & 2 & 3 & & & 0 & & 1 & & 1 & 9 & & & & & & $\ldots$ & & & & 4 & & 3 & \\
\hline
\end{tabular}

Figure 2Vehicles in Atatürk Boulevard with 3 lanes. The values in the cells symbolize vehicle velocity. If a value is 0 , it means that vehicle is stopped.

\subsection{CA Process}

The locations and the velocities of the vehicles are updated according to the basic CA rules. Driver reactions to traffic lights or other events (traffic congestion, traffic jam, traffic accident and so on) are differing from person to person. These features are attached to the CA model with randomization probability parameter for increasing the system reality. According to S2S rule a vehicle moves either (1-Pslow) probability or Pslow probability. The randomization parameter of the developed system is determined depending on Pslow probability. In [9] traffic flow was calculated by moving vehicle numbers divided by number of cells. However it is believed that traffic flow is a function of the vehicle velocity and depends on time. So traffic flow must be calculated according to the following expression: 


$$
f=\frac{\sum_{t=0}^{t_{N}} N_{V}}{t_{N}} .
$$

In [4], traffic congestion was calculated as the number of vehicles divided by the number of cells for each simulation frame. But in the developed system some of the vehicles occupy only one cell, but the others may occupy multiple cells as depending on the different types of the vehicles. While both density and the flow are calculated, the cell state (empty or full) must be considered as well as occupation status. Logical map is updated according to the status of the cells as true or false in each simulation frame. The density of the system at time $t$ is calculated as the number of total true values divided by the number of total cells.

$d(t)=\frac{\sum N_{T}}{\sum C e l l}$.

Traffic jam needs to be taken into account as well as traffic congestion or traffic flow for optimizing the traffic system. Thus one of the evaluated criteria in the system is traffic jam. The reasons of traffic jam can be listed as traffic lights, sequential vehicles, intersections, and so on. Traffic jam affects the randomization probability since traffic jam takes a little longer time. Because increasing elapsed time in traffic jam affects driver reaction time. That's why traffic jam is calculated by the number of stopped vehicles divided by the total number of cells for each simulation frame. The value of the calculated traffic jam is one of the determining parameters of randomization probability parameter in the developed system.

$$
s(t)=\frac{\sum V_{0}}{\sum \text { Cell }} .
$$

\section{Simulation results}

Approximately $16 \mathrm{~km}$ road traffic is simulated in the system using 2166 cells. Traffic flow has been provided with speed limits (fixed or flexible) according to vehicle types. The simulation is carried through 12000 steps, but the first 500 steps are discarded. Flow, density and congestion values are saved for every simulation frame. It is shown graphically in Fig. 3.

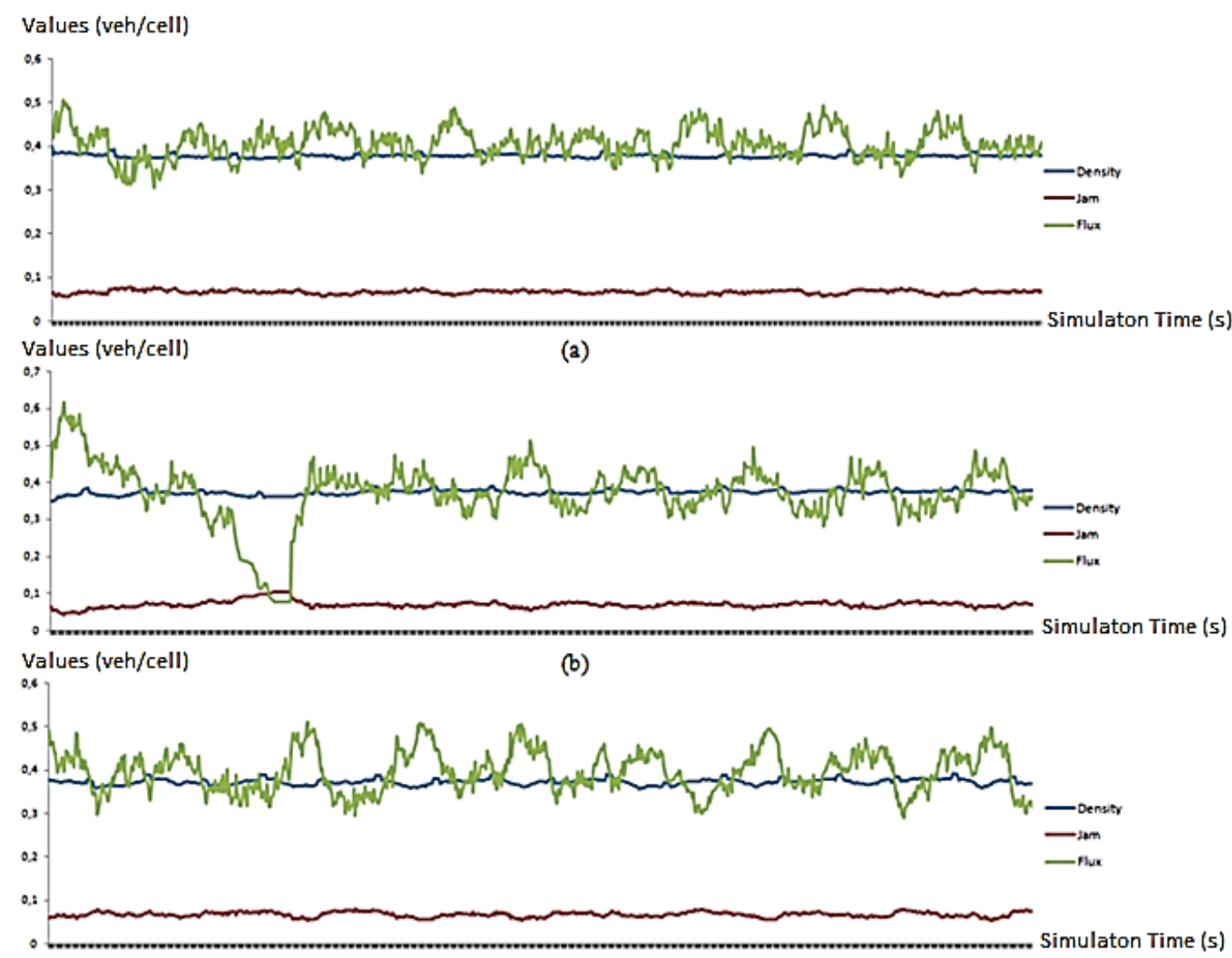

(c)

Figure 3 Density, jam and flux values a) $V_{\max }$ between 2 to $3, V_{\max }$ between 2 to $4, V_{\max }$ between 3 to 4

At low constant speed, although traffic jam fell down and traffic flow went up, the traffic congestion also went up. It was observed that at high constant speed the lowest value of the traffic congestion occurred, but at the same time traffic jam went up and traffic flow fell down.
According to the study flexible speed limits can be used to lower down traffic jam and traffic congestion and to improve traffic flow. At the same time the different types of vehicles have to obey different speed limits. Tab. 2 and Fig. 4 verify this observation. 


\begin{tabular}{|l|} 
Table 2 Average values of simulation results \\
\begin{tabular}{|l|c|c|c|c|c|c|}
\hline$V_{\max }$ & 2 & 3 & 4 & $2-3$ & $2-4$ & $3-4$ \\
\hline density & 0,3820 & 0,3790 & 0,3709 & 0,3791 & 0,3740 & 0,3739 \\
\hline jam & 0,0583 & 0,0603 & 0,0650 & 0,0655 & 0,0701 & 0,0664 \\
\hline flux & 0,4824 & 0,4641 & 0,4207 & 0,4187 & 0,3772 & 0,4094 \\
\hline
\end{tabular}
\end{tabular}

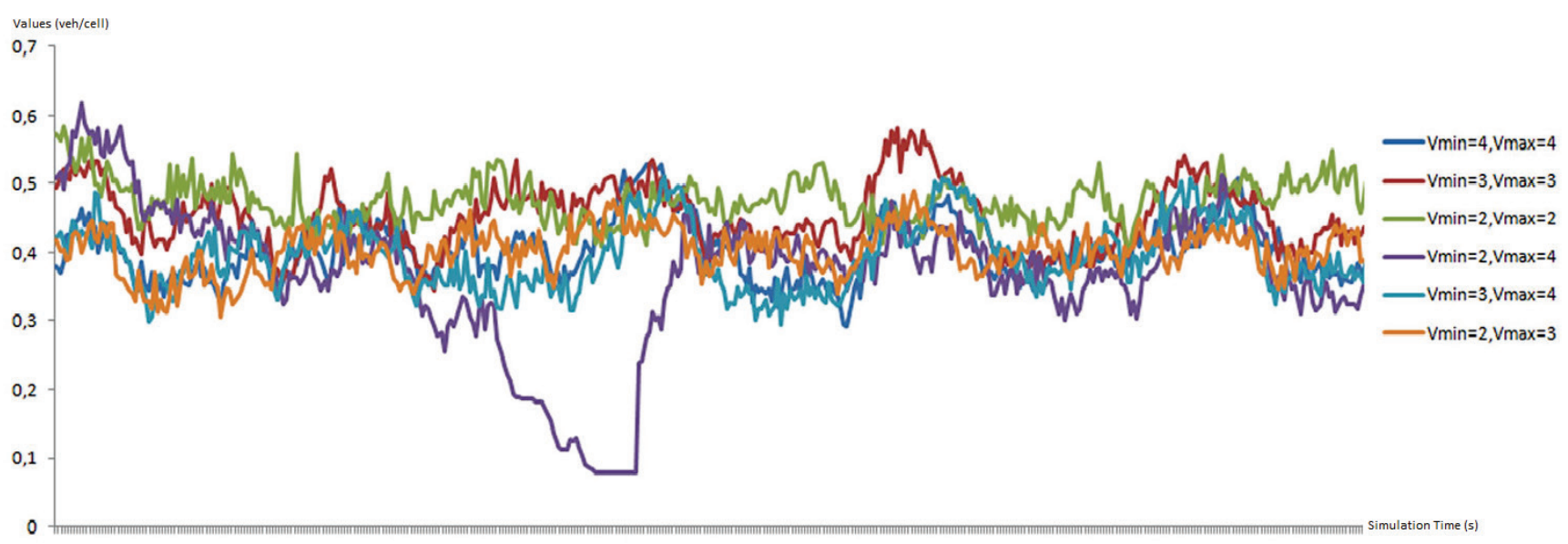

Figure 4 Traffic flow at different speed limits

\section{Conclusion}

In this study a traffic simulation model has been developed with employing the microscopic approach using CA. The model includes different types of vehicles that have different speed limits. The study put forth that the traffic congestion and the traffic jam are diminished and the traffic flow is enhanced when the vehicle's speeds are increased. Especially in the regions which have traffic congestion, traffic flow can be improved by not only limiting the vehicles maximum speed, but also limiting the vehicles minimum speed. The traffic flow can be improved by using variable traffic signs which are set as needed at different times of a day. By using the developed model in a vision system, the period of traffic lights can be adjusted in real time.

\section{References}

[1] Kurnaz, İ. Developing A Rule Based Platform for the Interactive Driver Education. // Ph.D Thesis, Karabük University Natural Sciences Institute, Karabük, 2012.

[2] Jiang, R. R.; Wua, Q. S. A stopped time dependent randomization cellular automata model for traffic flow controlled by traffic light. // Physica A. 364, (2006), pp. 493-496. DOI: 10.1016/j.physa.2005.10.038

[3] Wolfram, S. Cellular Automata. // Rev. Mod. Phys. 55, (1983), p. 601. DOI: 10.1103/RevModPhys.55.601

[4] Nagel, K.; Schreckenberg, M. A cellular automaton model for freeway traffic. // J. Phys. I France. 2, (1992), pp. 22212229. DOI: 10.1051/jp1:1992277

[5] Rickert, M.; Nagel, K.; Schreckenberg, M.; Latour, A. Two lane traffic simulations using cellular automata. // Physica A. 23, (1996), pp. 534-550. DOI: 10.1016/03784371(95)00442-4

[6] Barlovic, R.; Santen, L.; Schadschneider, A.; Schreckenberg, M. Metastable states in cellular automata for traffic flow. // Eur. Phys. J. B. 5, (1998), pp. 793-800. DOI: $10.1007 / \mathrm{s} 100510050504$

[7] Meng, Q.; Weng, Q. J. An improved cellular automata model for heterogeneous work zone traffic. // Transportation Research Part C. 19, (2011), pp. 1263-1275. DOI: 10.1016/j.trc.2011.02.011
[8] Bham, G. H.; Benekohal, R. F. A high fidelity traffic simulation model based on cellular automata and carfollowing concepts. // Transportation Research Part C. 12, 1(2004), pp. 1-32. DOI: 10.1016/j.trc.2002.05.001

[9] Benjamin, S. C.; Johnson, N. F.; Hui, P. M. Cellular automata models of traffic flow along a highway containing a junction. // J. Phys. A: Math. Gen. 29, (1996), pp. 31193127. DOI: $10.1088 / 0305-4470 / 29 / 12 / 018$

[10] Han, Y. S.; Ko, S. K. Analysis of a cellular automaton model for car traffic with a junction. // Theoretical Computer Science. 450, (2012), pp. 54-67. DOI: 10.1016/j.tcs.2012.04.027

[11] Wahle, J.; Neubert, L.; Esser, J.; Schreckenberg, M. A cellular automaton traffic flow model for online simulation of traffic. // Parallel Computing. 27, 5(2001), pp. 719-735. DOI: 10.1016/S0167-8191(00)00085-5

[12] Spyropoulou, I. Modeling a signal controlled traffic stream using cellular automata. // Transportation Research Part C. 15, (2007), pp. 175-190. DOI: 10.1016/j.trc.2007.04.001

[13] Nagatani, T. Traffic states and fundamental diagram in cellular automaton model of vehicular traffic controlled by signals. // Physica A. 388, (2009), pp. 1673-1681. DOI: 10.1016/j.physa.2008.12.046

[14] Tiana, J. F.; Jiaa, B.; Lia, X. G.; Jiangb, R.; Zhaoa, X. M.; Gaoa, Z. Y. Synchronized traffic flow simulating with cellular automata model. // Physica A. 388, (2009), pp. 4827-4837. DOI: 10.1016/j.physa.2009.07.043

[15] Ding, J.; Huang, H. A Cellular Automaton Model of Public Transport System Based on Cruise Control. J Transpn Sys Eng \& IT. 10, 1(2010), pp. 38-44. DOI: 10.1016/s15706672(09)60021-0

[16] Mua, R.; Yamamoto, T. An Analysis on Mixed Traffic Flow of Conventional Passenger Cars and Microcars Using a Cellular Automata Model. // Procedia - Social and Behavioral Sciences. 43, (2012), pp. 457-465. DOl: 10.1016/j.sbspro.2012.04.119

[17] Vasic, J.; Ruskin, H. J. Cellular automata simulation of traffic including cars and bicycles. // Physica A. 39, (2012), pp. 2720-2729. DOI: 10.1016/j.physa.2011.12.018

[18] Mauro, R.; Branco, F. Two Vehicular Headways Time Dichotomic Models. // Modern Applied Science. 6, 12(2012), pp. 1-12. DOI: 10.5539/mas.v6n12p1

[19] Mauro, R.; Branco, F.; Guerrieri, M. Contribution to the platoon distribution analysis in steady-state traffic 
conditions. // Periodica Polytechnica (Civil Engineering). 58, 3(2014), pp. 217-227. DOI: 10.3311/ppci.7472

[20] The Master Planning Project of Ankara Transportation System by Greater Municipality of Ankara and Gazi University, is going on.

[21] Wagner, P.; Nagel, K.; Wolf, D. E. Realistic multi-lane traffic rules for cellular automata. Physica A. 234, (1997), pp. 687-698. DOI: 10.1016/S0378-4371(96)00308-1

[22] Pasons, B. I. Trafikve Ulaşım İyileştirme Etüdü, Greater Municipality of Ankara, Ankara, 1998.

[23] Çavuşoğlu, A.; Kurnaz, İ. Developing a parameterized simulation platform with intelligent synthetic agents for training driver candidates. // Procedia Computer Science. 3, (2011), pp. 727-731. DOI 10.1016/j.procs.2010.12.120

[24] OpenGL The Industry's Foundation for High Performance Graphics, URL: http:// www.opengl.org/ May 2014.

[25] Lighthill, M. J.; Whitham, G. B. On Kinematic Waves. I. Flood Movement in Long Rivers. // Proc. R. Soc. A. 229, (1955), pp. 281-316. DOl: 10.1098/rspa.1955.0088

[26] Kerner, B. S.; Konhäuser, P. Structure and parameters of clusters in traffic flow. // Physical Review E. 50, 1(1994), pp. 54 -83. DOI: 10.1103/PhysRevE.50.54

[27] Bando, M.; Hasebe, K.; Nakayama, A.; Shibata, A.; Sugiyama, Y. Dynamical model of traffic congestion and numerical simulation. // Physical Review E. 51, 2(1995), pp. 1035-1042. DOI: 10.1103/PhysRevE.51.1035

[28] Pursula, M. Simulation of traffic systems-An overview. // Journal of Geographic Information and Decision Analysis. 3, 1(1999), pp. 1-9.

\section{List of Notations}

\begin{tabular}{|c|l|}
\hline$d_{\text {ahead }}$ & Distance between the vehicles \\
\hline$V_{\text {vehicle }}$ & Velocity of the vehicle \\
\hline$V_{\max }$ & Maximum speed of the vehicle \\
\hline$f$ & Traffic Flux \\
\hline$t_{\mathrm{N}}$ & Simulation Time \\
\hline$N_{\mathrm{v}}$ & Number of vehicle which speed $>0$ \\
\hline$d(t)$ & Traffic Density \\
\hline$N_{\mathrm{T}}$ & Number of true values \\
\hline$s(t)$ & Traffic Jam \\
\hline$V_{0}$ & Vehicles which speed $=0$ \\
\hline
\end{tabular}

\section{Authors' addresses}

\section{İsmail Kurnaz, Dr.}

Department of Computer Engineering

Karabuk University

Balıklarkayası Karabük, Turkey

E-mail: ikurnaz@karabuk.edu.tr 